\title{
Anticancer and Antimicrobial Activity of Red Sea Seaweeds Extracts-Mediated Gold Nanoparticles
}

\section{Rabaa Algotiml ${ }^{1,2}$, Ali Gab-alla ${ }^{3}$, Roshdi Seoudi ${ }^{4}$, Hussein H. Abulreesh ${ }^{1,2} \mathbb{D}$, Iqbal Ahmad ${ }^{5}$ (D) and Khaled Elbanna ${ }^{1,2,6 *}$ (i)}

\footnotetext{
${ }^{1}$ Department of Biology, Faculty of Applied Science, Umm Al-Qura University, Makkah, Saudi Arabia. ${ }^{2}$ Research Laboratories Unit, Faculty of Applied Science, Umm Al-Qura University, Makkah, Saudi Arabia ${ }^{3}$ Department of Marine Sciences, Faculty of Sciences, Suez Canal University, Ismailia, Egypt.

${ }^{4}$ Department of Spectroscopy, Physics Division, National Research Center, Dokki, Cairo 12622, Egypt ${ }^{5}$ Department of Agricultural Microbiology, Faculty of Agricultural Sciences, Aligarh Muslim University, Aligarh - 202 002, Uttar Pradesh, India.

${ }^{6}$ Department of Agricultural Microbiology, Faculty of Agriculture, Fayoum University, Fayoum, Egypt.
}

*Correspondence: kab00@fayoum.edu.eg

(Received: September 10, 2021; accepted: December 2, 2021)

Citation: Algotiml R, Gab-alla A, Seoudi R, Abulreesh HH, Ahmad I, Elbanna K. Anticancer and Antimicrobial Activity of Red Sea Seaweeds Extracts-Mediated Gold Nanoparticles. J Pure App/ Microbiol. 2022;16(1):207-225. doi: 10.22207/JPAM.16.1.11

(C) The Author(s) 2022. Open Access. This article is distributed under the terms of the Creative Commons Attribution 4.0 International License which permits unrestricted use, sharing, distribution, and reproduction in any medium, provided you give appropriate credit to the original author(s) and the source, provide a link to the Creative Commons license, and indicate if changes were made. 


\begin{abstract}
Biosynthesis of gold nanoparticles (AuNPs) is emerging as a better alternative to traditional chemicalbased techniques. During this study, extracts of different marine algae species Ulva rigida (green algae), Cystoseira myrica (brown Algae), and Gracilaria foliifera (red Algae) were utilized as reducing and capping agents to synthesize AuNPs. AuNPs capped by U. rigida, C. myrica, and G. foliifera were confirmed by the appearance of surface plasmonic bands at 528, 540, and $543 \mathrm{~nm}$, respectively. Transmission electron microscopy revealed mostly spherical shapes of AuNPs having a size of about 9 $\mathrm{nm}, 11 \mathrm{~nm}$, and $13 \mathrm{~nm}$ for $C$. myrica, and G. foliifera extracts, respectively. Fourier transform-infrared spectroscopy (FTIR) illustrated the major chemical constituents of $U$. rigida, $C$. myrica, and $G$. foliifera. LC50 values of the biosynthesized AuNPs against Artemia salina nauplii were calculated at a range of concentrations (5-188 $\mathrm{g} \mathrm{m} \mathrm{m}^{-1}$ ) after 16 to $24 \mathrm{~h}$. AuNPs concentration-dependent lethality was noted and $U$. rigida extracts-mediated AuNPs presented the lowest cytotoxicity. The biosynthesized AuNPs exhibited significant anticancer activity $(\mathbf{8 6 . 8 3 \%})$ against MCF-7 cell lines (human breast adenocarcinoma cell lines) at $188 \mu \mathrm{g} / \mathrm{ml}$ concentration. G. foliifera demonstrated the highest anticancer value (92.13\%) followed by $C$. myrica $(89.82 \%)$, and $U$. rigida ( $86.83 \%)$, respectively. The AuNPs synthesized by different algal extracts showed variable antimicrobial activity against the tested pathogenic microorganisms. AuNPs of $U$. rigida extracts showed significant antimicrobial activity against dermatophytic fungi Trichosporon cataneum ( $30 \mathrm{~mm}$ ) followed by Trichophyton mantigrophytes ( $25 \mathrm{~mm}$ ). Furthermore, it also exhibited mild activity against Escherichia coli $(17 \mathrm{~mm})$, Cryptococcus neoformans $(15 \mathrm{~mm})$, Candida albicans $(13 \mathrm{~mm})$, and Staphylococcus aureus $(11 \mathrm{~mm})$, respectively whereas no effects were observed against Bacillus cereus. To conclude, AuNPs can be effectively synthesized by marine algal species, and particularly $U$. rigida extracts could be effective reducing agents for the green AuNPs synthesis. These AuNPs could potentially serve as efficient alternative anticancer agents against human breast adenocarcinoma and anti-dermatophytes associated with skin infections.
\end{abstract}

Keywords: Marine algae, biosynthesized gold nanoparticles, cytotoxicity, Artemia salina, anticancer, breast cancer cell lines, antibacterial, antifungal, Dermatophytes

\section{INTRODUCTION}

Seaweeds are potentially bioactive plants that flourish in marine or brackish water environments. Seaweeds are a renewable, biological, and ecological component of marine environments. They substantially contribute to primary marine production and serve as a habitat for many near-shore benthic communities. Algae constitute about $90 \%$ of marine plant species and contribute to approximately $50 \%$ of global photosynthesis. The importance of algae is multiplied by the fact that every second oxygen molecule inhaled by humans is derived from algae, and similarly, every second carbon dioxide molecule exhaled by humans is used by algae. ${ }^{1}$ There are three groups of algae including red algae (Rhodophyta), brown algae, and green algae (Chlorophyta). Marine algae are rich in polysaccharides (fucoidan, alginate, laminarin, agar, carrageenan), polyphenols, minerals, carotenoids, amino acids, proteins, and vitamins, ${ }^{2-7}$ which are broadly used in manufacturing, medicine, and food industries. ${ }^{8}$ Algal phytochemicals contain carboxyl, amino functional groups, and hydroxyl, which are effective capping and metal-reducing agents and provide a robust coating on the gold during one-step synthesis. ${ }^{9}$ At present, different chemical and physical methods are employed to synthesize gold (AuNPs) nanoparticles. However, there is still an urge to develop new techniques for the economical, commercially viable, and environmentally safe synthesis of AuNPs. ${ }^{3,5,6}$ The biological synthesis of AuNPs without toxic chemicals has numerous outstanding benefits and is an advanced technique as compared to traditional physical and chemical methods. ${ }^{3-6}$ Promotes clearance, biocompatibility, and efficient binding in addition to the assessment of their long-term impacts on different biological systems including human reproduction and health. ${ }^{10} \mathrm{Gold}$ is an unreactive noble element that does not undergo chemical oxidation. The brilliant luster of historical gold artifacts was still preserved after thousands of years. Therefore, the use of gold in electronics 
coinage, and jewelry is well known. For example, thin gold films $(20 \mathrm{~nm})$, which are commonly found in office windows allow the passage of visible light and efficiently reflect the infrared light $(\mathrm{l}>800 \mathrm{~nm})$. This phenomenon helps in retaining the heat during winter and pushes out the warm air during summer. ${ }^{10}$ Biomedical applications of gold nanoparticles became common since their first colloidal syntheses. Their attractive colors and distinctive electronic characteristics combined with historical artifacts and ancient medicinal applications have attracted tremendous attention for current usage in photovoltaics and enhanced optoelectronics. The properties of gold nanoparticles are generally based on their shape and size. Their role is becoming prominent in various aspects such as computer transistors, antimicrobial activity, electrometers, wireless electronic logic, bio-sensing, anticancer activity, memory schemes, and chemical sensors. ${ }^{9}$ The physical properties of gold nanoparticles are quite different from small molecules, bulk materials, and other nanoscale particles. Seaweedsmediated nanoparticles synthesis has been revealed in several studies, ${ }^{10,11,3-5}$ their biological applications, ${ }^{12-14,3-6}$ and cytotoxicity properties. ${ }^{15}$ The unique properties of gold nanoparticles are being further explored for their expanding role in medical diagnostics and therapeutics. ${ }^{10}$ During the present study, marine seaweeds (Ulva rigida, Cystoseira myrica, and Gracilaria foliifera) were collected from the Red Sea coast of Jeddah, Saudi Arabia. These seaweeds were used for the biosynthesize of gold nanoparticles and their bioactivity was evaluated. Artemia salina nauplii and the skin normal cell lines (HFb-4) were used to assess their cytotoxicity whereas antifungal and antibacterial activities were studied against the foodborne pathogens and dermatophytic fungi. Their anticancer potential was also elaborated against human breast adenocarcinoma cell lines (MCF-7).

\section{MATERIALS AND METHODS Algal Sample Preparation}

$U$. rigida, C. myrica and $G$. foliifera fresh seaweeds were collected from the Red Sea coast of Jeddah, Saudi Arabia. Polythene bags were used to carry the samples to the laboratory and rinsed in freshwater for removing impurities. Then, the algae were again cleaned using a brush to remove the epiphytes, dust, and attached organisms and washed twice with distilled water. The cleaned algae were dried at room temperature in the shade for a week. Thoroughly dried samples were ground to a powder, sieved $<0.5 \mathrm{~mm}$, and stored at $4^{\circ} \mathrm{C}$ until used according to Isaac and Renitta. ${ }^{16}$ Seaweeds were morphologically identified according to Pereira and Neto. ${ }^{17}$

\section{Preparation of Seaweed Water Extracts}

Ten grams of each algal powder was mixed in $400 \mathrm{ml}$ deionized water and heated for $15 \mathrm{~min}$ at $70^{\circ} \mathrm{C}$. Algal precipitates were filtered through Whatman paper No. 1. The filtration step was repeated three times until clear extracts were obtained, which were stored at $4^{\circ} \mathrm{C}$ until used according to Krishnamoorthy et al. ${ }^{18}$

\section{Preparation of Seaweed Ethanol Extracts}

Dried seaweed powder (10 gm) was soaked in $200 \mathrm{ml}$ ethanol (95\%) and shaken at room temperature for $24 \mathrm{~h}$. Then, Whatman paper No. 1 was used to filter the mixture, and the extracts were evaporated to dryness in a rotary evaporator at $45^{\circ} \mathrm{C}$. Stock solution $\left(200 \mathrm{mg} / \mathrm{ml} \mathrm{H}_{2} \mathrm{O}\right)$ of each algal extract was prepared for further studies. were prepared to determine the antimicrobial activity of biosynthesized nanoparticles according to Abdelraouf. $^{19}$

\section{Synthesis of AuNPs using Different Marine Algal} Extracts

Gold nanoparticles (AuNPs) were biosynthesized using different algal extracts according to Dhas et al. ${ }^{20}$ Gold chloride (AuCl3) having a molecular weight of $303.33 \mathrm{~g} / \mathrm{mol}$ was purchased from Koch-Light Laboratories Ltd. (USA) and dissolved in the distilled water at a molar concentration of $10^{-3} \mathrm{M} .80 \mathrm{ml}$ gold solution was added to $20 \mathrm{ml}$ of each algal extract (20\%) in a conical flask to prepare the AuNPs. ${ }^{21}$ The formation of AuNPs changed the color from yellow to dark purple because of surface irritation and plasma vibrations of the nanoparticles, as shown in Fig. 1. Au concentration in the solution was about $188 \mu \mathrm{g} / \mathrm{ml}$. The biosynthesized AuNPs solutions were gently mixed, cooled, and stored at room temperature until used for further studies.

\section{Physiochemical Characterization}

Ultraviolet-visible spectra of the biosynthesized AuNPs capped by different algal extracts were measured at a resolution 
of $2 \mathrm{~nm}$ in Thermo-scientific Evolution 220 Spectrophotometer whereas the absorption spectra were determined at 200-900 nm wavelength. The nanoparticles distributions, shape, and particle size were studied using the JEOL JEM-1100 microscope (JEOL Ltd., Tokyo, Japan). To obtain Transmission Electron Microscope (TEM) measurements with a homogeneous distribution of nanoparticles colloidal in a copper grid, nanoparticles were dispersed in the solution for about 5 minutes using an ultrasonication device, and a suspension droplet was immediately placed on the copper grid and dried under room conditions. ${ }^{22}$ To detect the functional groups involved in the biosynthesized AuNPs and molecules present in the seaweed extracts, a disk of $50 \mathrm{mg} \mathrm{KBr}$ was prepared with a mixture of $2 \%$ finely dried specimens were prepared and examined using Fourier Transform Infrared Spectrometer (Jasco Model 300E). ${ }^{23}$ The spectra of seaweed extracts and biosynthesized AuNPs were measured at the wavenumber range of $500-4000 \mathrm{~cm}^{-1}$ to detect the potential functional groups involved in the capping and reduction of biomolecules present in the seaweed extracts.

\section{Assessment of Cytotoxicity using Brine Shrimp Artemia Salina}

Artemia salina cysts were used for the preparation of larvae, which were maintained under laboratory conditions. Artemia salina cysts $(0.75 \mathrm{~g})$ were suspended in $100 \mathrm{ml}$ of $3.2 \%$ saline solution $(3.2 \mathrm{~g} \mathrm{NaCl}$ in $100 \mathrm{ml}$ distilled water) inside a $500 \mathrm{ml}$ glass jar. Continuous aeration was carried out at $25-29^{\circ} \mathrm{C}$ under the candescent lamp (40-60 watts) for $36 \mathrm{~h}$ for the hatching of Artemia salina larvae. Actively free-floating nauplii were collected under bright illumination after hatching and stored until used in cytotoxicity assays. The fraction test of serial fold concentrations of gold nanoparticles $(5-188 \mu \mathrm{g} / \mathrm{ml})$ was carried out to determine the toxicity of gold nanoparticles capped by different algal species (U. rigida, $C$. myrica, and $G$. foliifera). The freshwater was used as a negative control (without AuNPs). Ten shrimp larvae with $5 \mathrm{ml}$ solution were used in each treatment and incubated at $25^{\circ} \mathrm{C}$ under illumination for 24 hours. Finally, the dead and live larvae were counted under a magnifier, and the $\mathrm{LC}_{50}$ value was calculated according to Azizi. ${ }^{24}$

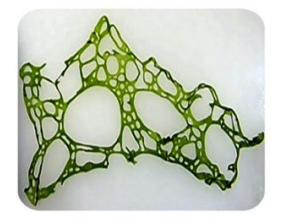

(a) $\boldsymbol{U}$. rigida

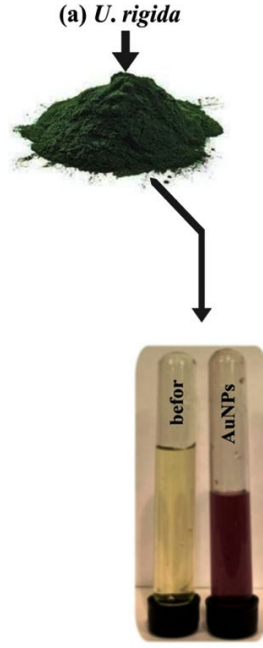

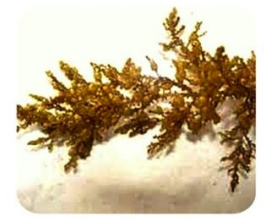

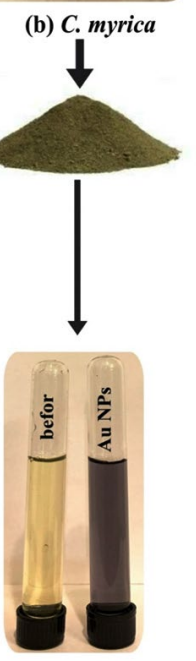

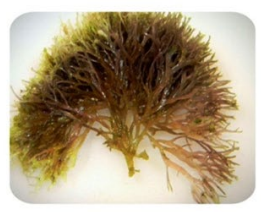
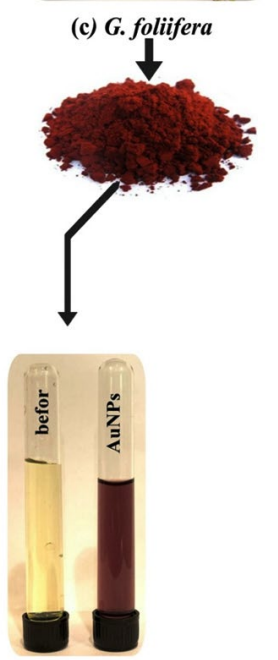

Fig. 1. Biosynthesis of AuNPs using different marine algal extracts: (a) U. rigida, C. myrica, and G. foliifera as reducing and capping agents. The reduction of $\mathrm{HAuCl}_{4}$ by the algal extracts was visually evident from the color change (purple) of the reaction mixture after $48 \mathrm{~h}$. 
Mortality $\%=\Sigma$ dead test larvae $-\Sigma$ dead control larvae $/ \Sigma$ test larvae $\times 100$

Cytotoxicity Assessment of Biosynthesized AuNPs against Skin Cell Line ( $\mathrm{Hfb}-4)$

The cytotoxicity of biosynthesized AuNPs against skin cell lines (Hfb-4 cell lines) was determined using 96 -well plates..$^{25}$ Serial fold concentrations $\left(0-188 \mu \mathrm{g} \mathrm{ml}^{-1}\right)$ of both algalcapped synthesized AuNPs and non-biogenic AuNPs were prepared and the viability of $\mathrm{Hfb}-4$ cell lines was assessed after $24 \mathrm{~h}$. A medium containing the cells without AuNPs served as a control. The medium was removed after the incubation period and $5 \mu \mathrm{g} \mathrm{m}^{-1}$ concentration of another medium MTT (3-(4,5- dimethylthiazol-2yl) -2,5-diphenyltetrazolium bromide) was added to the cells without AuNPs for $2 \mathrm{~h}$ in dark at 37 ${ }^{\circ} \mathrm{C}$ dark and reductive metabolism was detected in the cells for cytotoxicity, proliferation, and viability assays. The absorbance of the solution was measured at $570 \mathrm{~nm}$ and compared with the $690 \mathrm{~nm}$ wavelength. The following equation was employed to calculate the AuNPs cytotoxicity:

Cell viability $(\%)=$ Mean Absorbance of sample / Absorbance of control $\times 100$
Estimation of Anticancer Activity of Biosynthesized AuNPs using Human Breast Cancer Cell Line (MCF-7).

Anticancer properties of the biosynthesized AuNPs was evaluated through Cancer Lab, Vacsera Institute, Giza, Egypt using the human breast cancer cell line (MCF-7) according to Skehan et al. ${ }^{26}$ Anticancer potential of the biosynthesized AuNPs was determined using MCF-7 by following the sulforhodamine B (SRB) method. ${ }^{27} \mathrm{~A}$ 96-well microtiter plates were used to culture the MCF- 7 cells $\left(3 \times 10^{3}\right.$ cell/well) in a fresh medium $(150 \mathrm{ml})$ and incubated at $37^{\circ} \mathrm{C}$ inside a $\mathrm{CO}_{2}$ incubator for $24 \mathrm{~h}$ to allow the cells to attach to the plates. Later on, serial fold concentrations of the biosynthesized and non-biogenic AuNPs (0-188 $\left.\mathrm{g} \mathrm{ml}^{-1}\right)$ were added to the wells containing MCF-7 cells and incubated for $48 \mathrm{~h}$. Subsequently, the cells were fixed by trichloroacetic acid (50\%), washed with distilled water and finally stained by sulforhodamine B (SRB) method and an ELISA microplate reader was used to measure the optical density of each well at $570 \mathrm{~nm}$. The percentage of relative viability and $I C_{50}$ (half-maximal inhibitory concentration) was estimated using master ples-

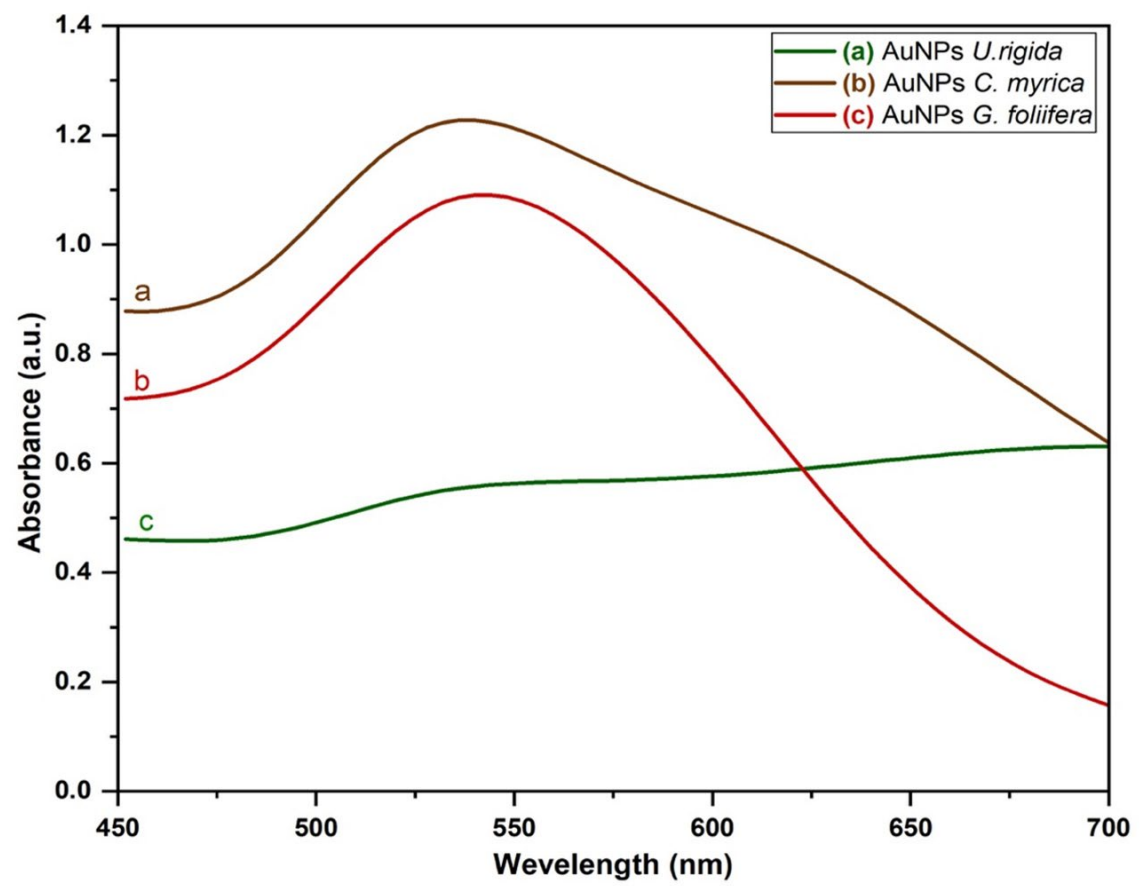

Fig. 2. UV-vis spectra of the biosynthesized AuNPs capped by different marine algal extracts (a) $U$. rigida, (b) $C$. myrica, and (c) G. foliifera. 
2010. Cell viability percentage was calculated using the following formula:

Cell viability $(\%)=$ Mean Absorbance of sample / Absorbance of control × 100 .

Determination of Antimicrobial Activity

Bacterial and Fungi Strains used in the study

Antimicrobial efficacy of biosynthesized

AuNPs $(188 \mu \mathrm{g} / \mathrm{ml})$ capped by different algal species (U. rigida, C. myrica, and G. foliifera) were assessed against Gram-positive pathogenic bacteria Bacillus cereus (DSM 31), and S. aureus (ATCC8095), and Gram-negative bacteria E. coli (ATCC 25922). The potential of algal AuNPs was also assessed against molds and dermatophyte fungi such as Candida albicans (ATCC 10231), Trichosporon cataneum, and Trichophyton mantigrophytes. All fungi were obtained from the fungi center, Assiut University, Egypt. Nutrient agar slants were used to maintain
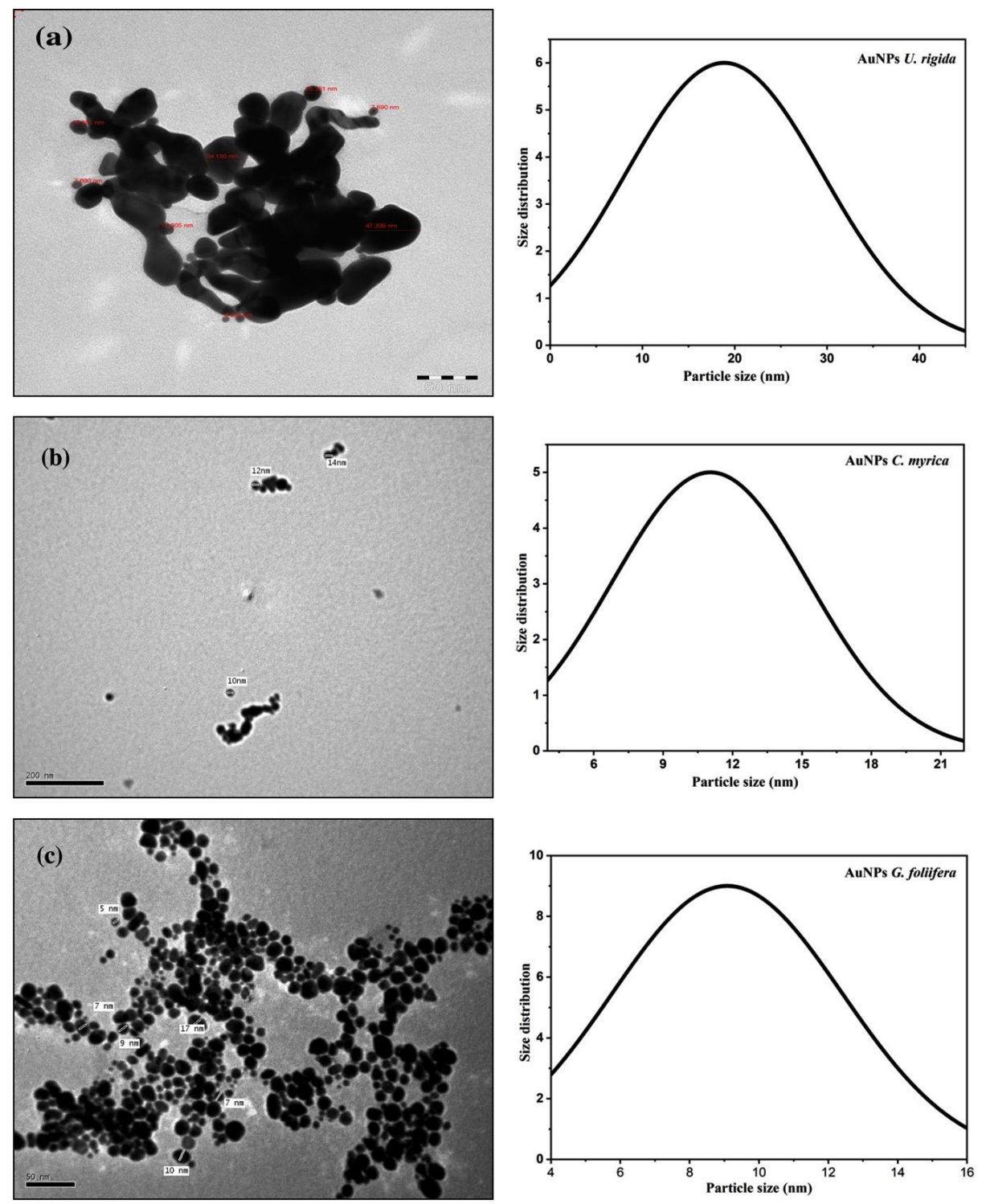

Fig. 3. TEM images of biosynthesized AuNPs capped by different marine algal extracts (a) U. rigida, (b) C. myrica, and (c) G. foliifera. 
the bacterial stock cultures at $4^{\circ} \mathrm{C}$, while potato dextrose agar slants were used to maintain candida yeast and fungi at $4^{\circ} \mathrm{C}$.

The antimicrobial activity of AuNPs was assessed by the agar well diffusion method according to Torres et al. ${ }^{28}$ and Elbanna et al..$^{29}$ The diameter of clear zones $(\mathrm{mm})$ around the wells was measured to determine antimicrobial activity. The controls were only treated with water. The agar disk diffusion method was followed to assess the antibacterial activity of antibiotics according to Bauer et al..$^{30}$ by measuring the diameter $(\mathrm{mm})$ of clear zones around each well. Augmentin $(30 \mu \mathrm{g})$, Chloramphenicol $(30 \mu \mathrm{g})$, Gentamycin $(30 \mu \mathrm{g})$, and Fluconazole $(100 \mu \mathrm{g} / \mathrm{ml})$ were used as standards to compare the results of antibacterial and antifungal tests, respectively.

\section{Determination of Minimum Lethal Concentrations (MLC)}

A serial fold dilution method was adopted to determine the minimum lethal concentrations (MLCs) of biosynthesized AuNPs against pathogenic microorganisms according to Abdel-raouf ${ }^{19}$ and Murugesan. ${ }^{31}$ Serial fold concentrations of biosynthesized AuNPs were added in the tubes already containing either $4 \mathrm{ml}$ of potato dextrose broth medium or LB for Candida albicans or pathogenic bacteria, respectively. The tubes were separately inoculated with $0.4 \mathrm{ml}(0.5$ McFarland) medium and bacterial test species ( $1 \times 10^{6}$ cells $\left./ \mathrm{ml}\right)$. In the case of pathogenic fungi, serial fold concentrations of biosynthesized AuNPs were added in the tubes already containing PD broth $(4 \mathrm{ml})$. The tubes were separately inoculated with fungal spores $\left(1 \times 10^{6}\right)$. The tubes were separately incubated under suitable conditions for each microorganism. $0.1 \mathrm{ml}$ solution was withdrawn from each tube after the completion of the incubation period and sub-cultured PDA plates or LB agar, which were again incubated under suitable conditions for each microorganism. The lowest concentration of biosynthesized AuNPs with less than $0.1 \%$ viable count of the original inoculum $\left(1 \times 10^{6} \mathrm{cell} / \mathrm{ml}\right)$ was considered as the minimal lethal concentration (MLC).

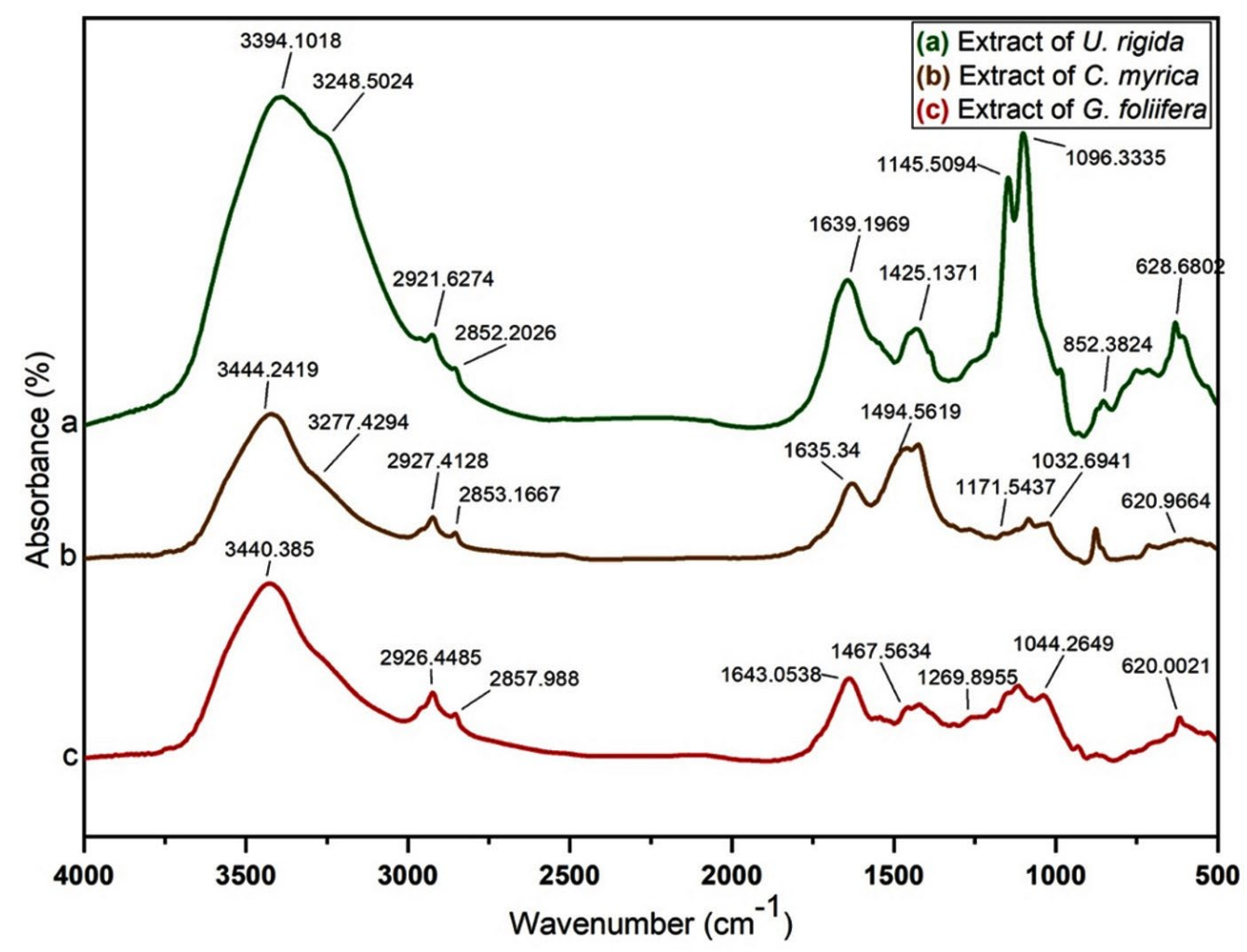

Fig. 4. FTIR spectra of different marine algal aqueous extracts (a) U. rigida, (b) C. myrica, and (c) G. foliifera. 


\section{RESULTS AND DISCUSSION UV-Vis Spectroscopy analysis}

The change of color (dark purple) in the reaction mixture demonstrated the reduction of $\mathrm{AuCl}_{4}$ by $U$. rigida, C. myrica, and $G$. foliifera. The incubation period was found to be directly proportional to the intensity of the dark purple color (Fig.1). UV-Vis spectra of AuNPs formed by different algal species extracts as a stabilizing material are shown in Fig. 2. Absorption peaks of AuNPs at 528, 540, and $543 \mathrm{~nm}$ capped by $U$. rigida, $C$. myrica, and $G$. foliifera were assigned to the surface plasmonic band resonance (SPR). A collective electron excitation led to the appearance of SPR on the surface of AuNPs. The increasing particle size shifted the absorption band to higher wavelengths in AuNPs capped by $U$. rigida, $C$. myrica, and $G$. foliifera, respectively.

The absorption bands at 528, 540, and $543 \mathrm{~nm}$ indicate the formation of gold in the nano dimension. These peaks are known as the surface plasmonic band resonance (SPR), which appear broad and less prominent due to polydispersity in the samples. ${ }^{31}$ The size and aspect ratio of NPs significantly affects the wavelength of absorbed light. The particle size variations in the solutions develop different colors. The conduction electrons present on the nanoparticle surface vibrate in response to a particular light wavelength leading to the formation of different vibrant colors. These vibrations produce extremely bright colors depending upon the particle shape and size. ${ }^{32}$

\section{Transmision Electron Microscope (TEM)}

TEM images of AuNPs stabilized by $U$. rigida, $C$. myrica, and $G$. foliifera are presented in Fig. (3:a-c). AuNPs capped by $U$. rigida (Fig. 3a) were primarily made of the spherical and compressed matrix of $9 \mathrm{~nm}$ that were hexagonal and well-distributed without aggregation in solution. TEM images of AuNPs stabilized by $C$. myrica revealed it as mostly spherical with some aggregation and also depicted some rod-shaped dark points. The regular average particle size was estimated as $11 \mathrm{~nm}$ (Fig. 3b). TEM images of AuNPs

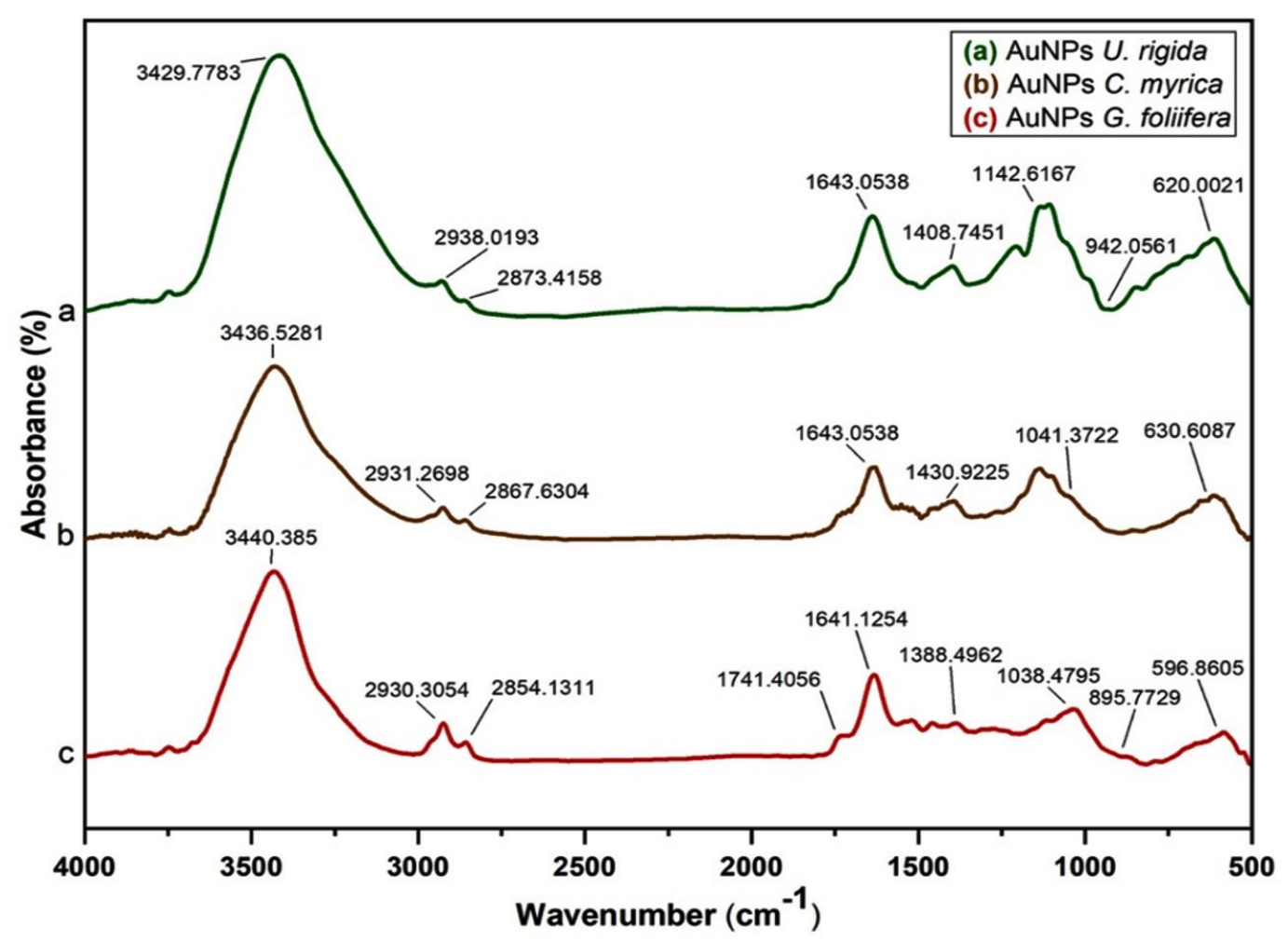

Fig. 5. FTIR spectra of biosynthesized AuNPs capped by different marine algal extracts: (a) U. rigida, (b) C. myrica, and (c) G. foliifera. 


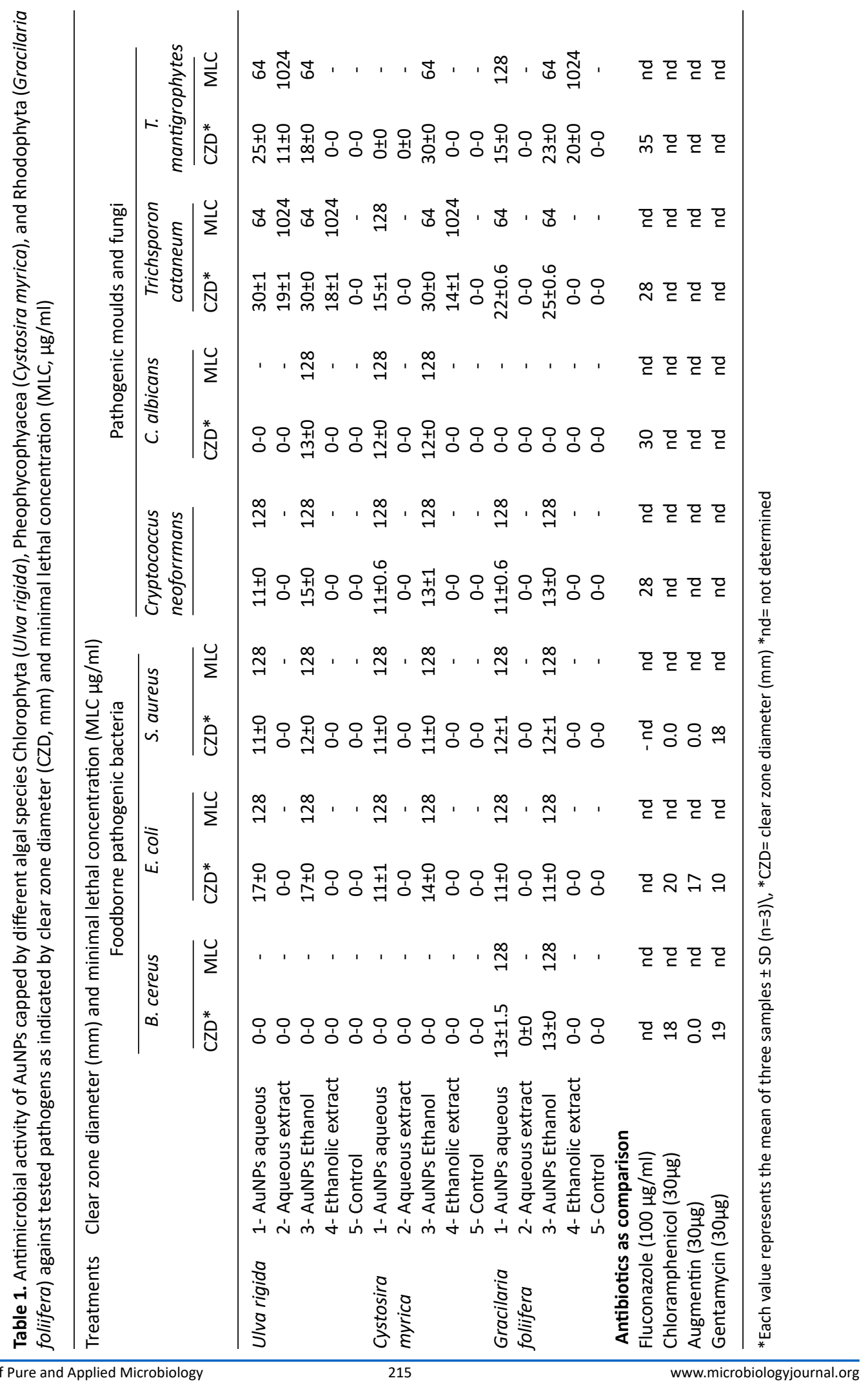


stabilized by G. foliifera (Fig. 3c) were observed as dark points of spherical and triangle shapes having an average size of $13 \mathrm{~nm}$. As reported in earlier studies, algal-mediated AuNPs are mostly possessed spherically shaped NPs. ${ }^{33,34}$

\section{FTIR spectroscopy analysis}

FTIR spectroscopy is applied to study the surface chemistry of AuNPs and the algal extracts to identify the functional groups found on the surfaces ${ }^{34}$. FTIR spectrums of the algal
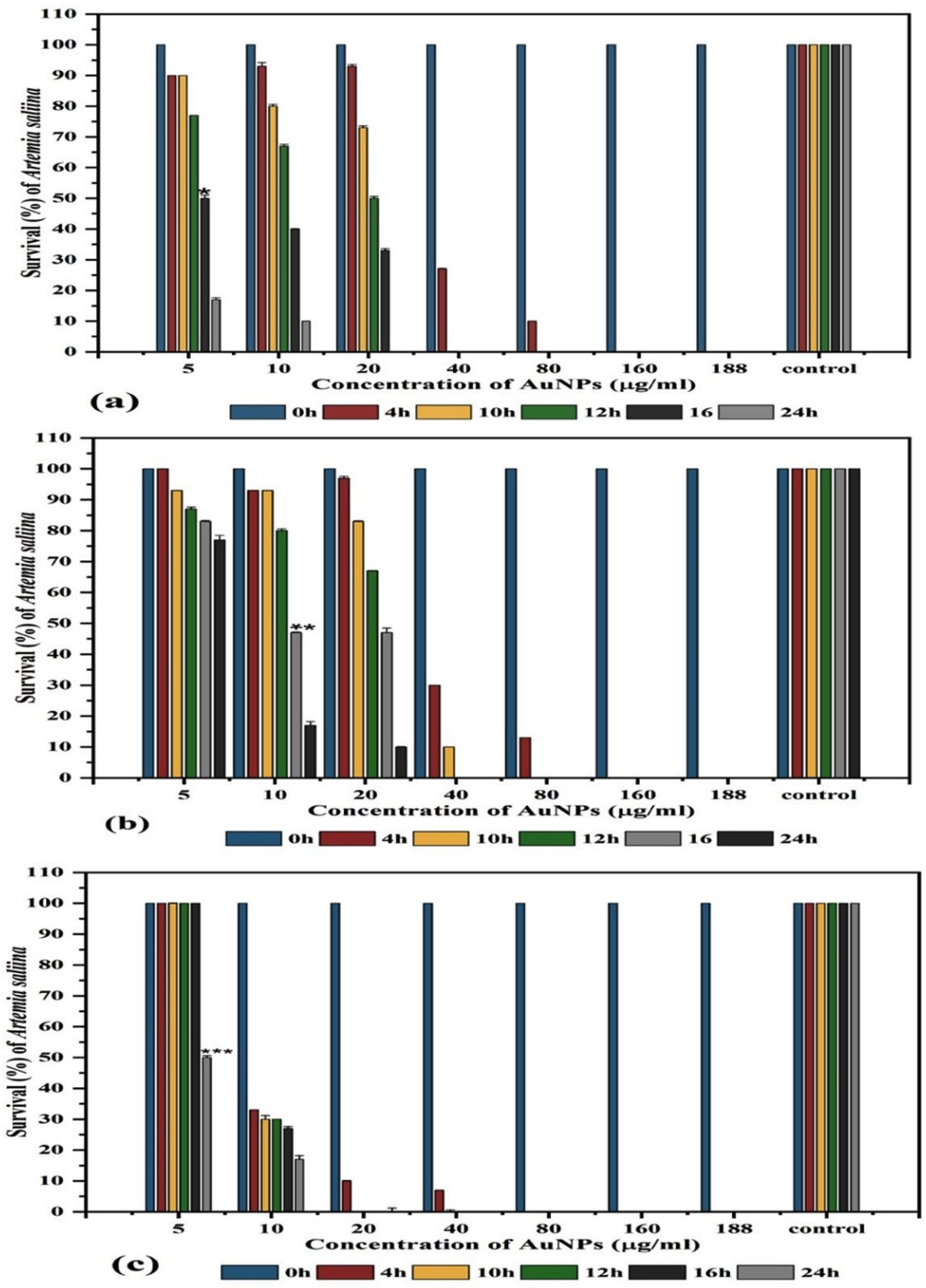

Fig. 6. Survival (\%) of Artemia salina nauplii (10) treated with different concentrations $(\mu \mathrm{g} / \mathrm{ml}$ ) of biosynthesized AuNPs capped by different marine algal extracts: (a) U. rigida, (b) C. myrica, (c) G. foliifera, and control (freshwater without AuNPs) after 24 hours. ${ }^{*}=\mathrm{LC}_{50}$ of $U$. rigida (Fig.6 a), ${ }^{* *}=\mathrm{LC}_{50}$ of $C$. myrica (Fig. 6 b), and $* * *=\mathrm{LC} 50$ of $G$. foliifera (Fig. 6 c). Each value represents the mean of three samples \pm SD $(n=3)$ 
extracts (U. rigida, $C$. myrica, and $G$. foliifera) were measured at $4000-500 \mathrm{~cm}^{-1}$. Two prominent peaks at 3394 and $3248 \mathrm{~cm}^{-1}$ (Fig. 4 a) indicated the presence of $\mathrm{O}-\mathrm{H}$ and $\mathrm{N}-\mathrm{H}$ stretching vibration of proteins and terpenoids in U. rigida. Two bands at 2919 and $2852 \mathrm{~cm}^{-1}$ revealed asymmetric and symmetric stretching vibrations of $\mathrm{CH}_{3}$. Two peaks confirmed $\mathrm{C}=\mathrm{C}$ and $\mathrm{N}-\mathrm{C}$ group vibrations at 1425 and $1232 \mathrm{~cm}^{-1}$. The peak at $1096 \mathrm{~cm}^{-1}$ expressed the rocking bending vibrations of $\mathrm{C}-\mathrm{F}$ whereas the peak at $852 \mathrm{~cm}^{-1}$ was related to the $\mathrm{C}-\mathrm{C}$. The $\mathrm{C}-\mathrm{H}$ bending vibration was explained by the band at $628 \mathrm{~cm}^{-1}$. The absorbance bands of $C$. myrica at about $3444 \mathrm{~cm}^{-1}$ and $3277 \mathrm{~cm}^{-1}$ (Fig. 4b) were recognized as $\mathrm{O}-\mathrm{H}$ and $\mathrm{N}-\mathrm{H}$ stretching vibrations. The two peaks at $2927 \mathrm{~cm}^{-1}$ and $2853 \mathrm{~cm}^{-1}$ represented the asymmetrical and symmetrical stretching vibrations of $\mathrm{CH}_{3}$. The absorption bands at $1750 \mathrm{~cm}^{-1} 1635 \mathrm{~cm}^{-1}$ explained the $\mathrm{C}=\mathrm{C}$ and $\mathrm{C}=\mathrm{O}$ stretching vibrations. The peaks at $1494 \mathrm{~cm}^{-1}$ and $1032 \mathrm{~cm}^{-1}$ were assigned to the C-O-group vibrations and the rocking bending vibrations of $\mathrm{CH}_{2}$. The band at $809 \mathrm{~cm}^{-1}$ was related to the characteristic O-S-O stretching vibrations. The infrared spectrum of $G$. foliifera (Fig. 4c) showed a band at $3269 \mathrm{~cm}^{-1}$ related to the $\mathrm{N}-\mathrm{H}$ stretching vibrations. The two bands observed at about 2926 and $2858 \mathrm{~cm}^{-1}$ were assigned to asymmetrical and symmetrical stretching vibrations of $\mathrm{CH}_{2}$. The band at $1745 \mathrm{~cm}^{-1}$ explained the $\mathrm{C}=\mathrm{C}$ group stretching vibrations. The peaks observed at $1643 \mathrm{~cm}^{-1}$ and $1467 \mathrm{~cm}^{-1}$ were interpreted as the stretching vibration of the $\mathrm{C}=\mathrm{O}$ and $\mathrm{S}=\mathrm{O}$ groups. The band at $1317 \mathrm{~cm}^{-1}$ illustrated the stretching vibration of $\mathrm{C}-\mathrm{N}$ - whereas the band at $1124 \mathrm{~cm}^{-1}$ expressed $\mathrm{S}-\mathrm{O}$ rocking bending vibrations. The bands at about $1044 \mathrm{~cm}^{-1}$ and $620 \mathrm{~cm}^{-1}$ exhibited the bending vibration of $\mathrm{CH} 3$ and $\mathrm{C}-\mathrm{O}-\mathrm{C}$ groups. FTIR results indicated that terpenoids, polyphenols, carotenoids, carbohydrates, fatty acids, and lipids were the most dominant biomolecules in $U$. rigida extract whereas the dominant molecules in C. myrica included polyphenols, sulfonated polysaccharides (fucoidan), lipids, and sterols. Simultaneously, agar and sulfonated polysaccharides were detected in $G$. foliifera extract.

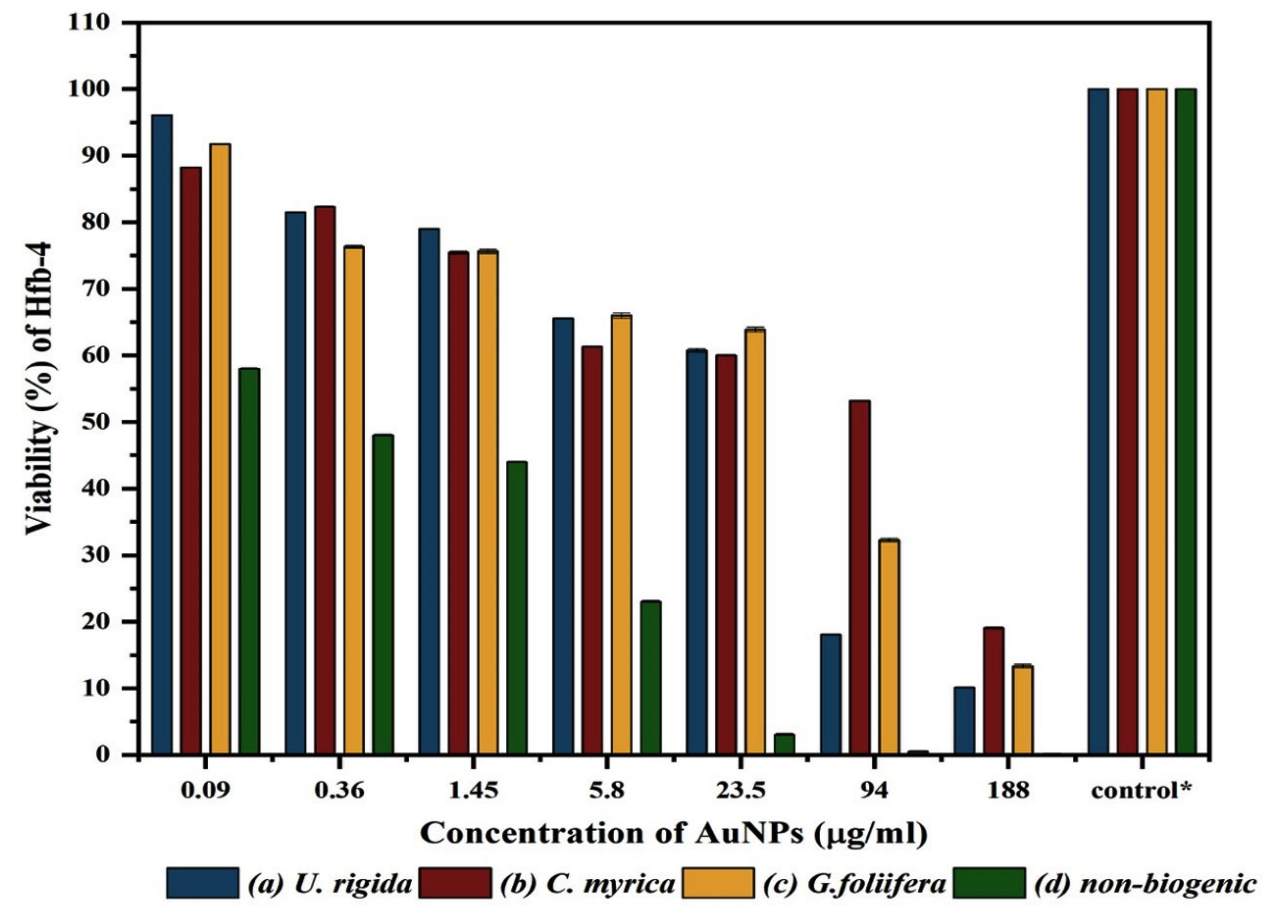

Fig. 7. Viability of Human skin cell line (HFb-4) treated with different concentrations $(\mu \mathrm{g} / \mathrm{ml})$ of biosynthesized AuNPs capped by different marine algal extracts: (a) U. rigida, (b) C. myrica, (c) G. foliifera, and (d) nonbiogenic AuNPs after 24 hours. Each value represents the mean of three samples $\pm S D(n=3)$. 
Fig. (5: a-c) depicts the absorbance spectra of AuNPs capped by U. rigida, C. myrica, and $G$. foliifera. These spectra were matched with the FTIR spectra of $U$. rigida, C. myrica, and $G$. foliifera extracts, which were investigated in the previous section. The absorption bands of algal extracts at 3394, 3444, and $3440 \mathrm{~cm}^{-1}$ shifted to 3440,3436 , and $3429 \mathrm{~cm}^{-1}$ for AuNPs capped by G. foliifera, C. myrica, and U. rigida, respectively. The absorption bands of AuNPs at 3236,3265 , and $3290 \mathrm{~cm}^{-1}$ varied with the extracts of different algal species. The bands appearing at 1639,1635 , and $1643 \mathrm{~cm}^{-1}$ in seaweeds were changed as well. The bands at 1096, 1032, and $1044 \mathrm{~cm}^{-1}$ turned to 1142,1041 , and $1038 \mathrm{~cm}^{-1}$ in AuNPs surrounding (U. rigida, C. myrica, and $G$. foliifera), respectively. These changes indicated the electrostatic interaction between AuNPs of different algal species and the functional groups $(\mathrm{OH}, \mathrm{N}-\mathrm{H}$, and $\mathrm{C}=\mathrm{O})$.

The functional groups serve as the reducing and capping during AuNPs biosynthesis. The identification of the type of capping agent is important as it regulates the efficacy of AuNPs. ${ }^{35}$
The capping agents stabilize the AuNPs by preventing particle aggregation and inhibiting particles interaction within Vivo components. ${ }^{36}$ Therefore, the surface-bound proteins possibly stabilize the gold nanoparticles. Furthermore, the FTIR has revealed that the protein peptides and carboxyl group of amino acid residues can strongly bind AuNPs. The proteins could form AuNPs covering coat to stabilize and prevent the accumulation of particles. These findings confirm that biological molecules could prepare and stabilize the AuNPs in the aqueous medium. The absorbance spectra of AuNPs biosynthesized by the extracts of different algal species were compared. The absorption bands of AuNPs biosynthesized by $U$. rigida, $C$. myrica, and $G$. foliifera extracts at 3394,3440 , and $3444 \mathrm{~cm}^{-1}$ (Fig. (4: a-c)) were respectively shifted to 3429,3436 , and $3440 \mathrm{~cm}^{-1}$ (Fig. (5: a-c)). The structural interchange due to the electrostatic interaction of AuNPs with $\mathrm{OH}$ of different functional groups in the algal species might be the reason behind this phenomenon. The peaks of AuNPs capped by U. rigida, C. myrica, and G. foliifera at 3248, 3277and $3269 \mathrm{~cm}^{-1}$ were

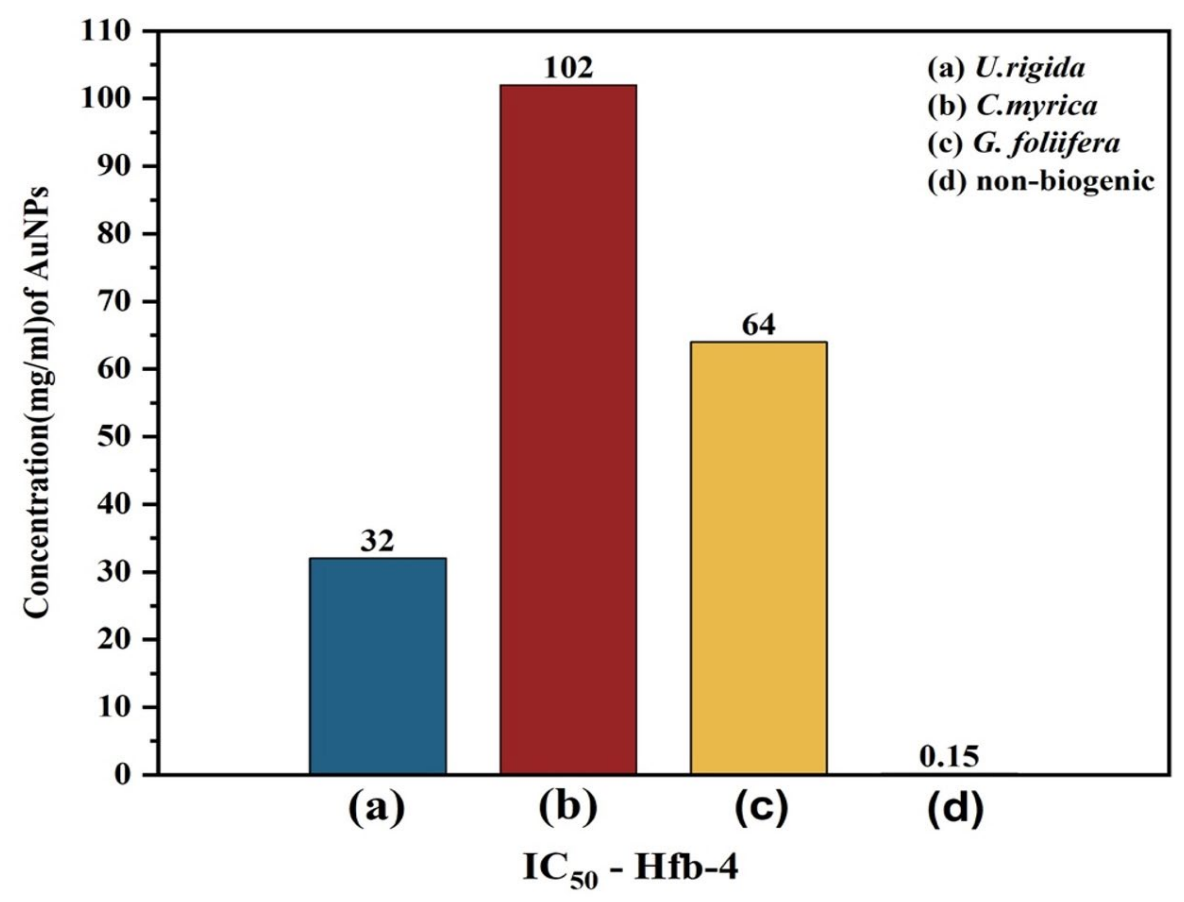

Fig. 8. $\mathrm{IC}_{50}$ of Human skin cell line (HFb-4) treated with different concentrations $(\mu \mathrm{g} / \mathrm{ml})$ of biosynthesized AuNPs capped by different marine algal extracts: (a) U. rigida, (b) C. myrica, (c) G. foliifera, and (d) nonbiogenic AuNPs after 24 hours. Each value represents the mean of three samples $\pm S D(n=3)$. 
moved to 3236,3265 , and $3290 \mathrm{~cm}^{-1}$. The bands at 1639, 1635, and $1643 \mathrm{~cm}^{-1}$ (Fig. (4: a-c) related to $\mathrm{C}=\mathrm{O}$ in $\mathrm{U}$. rigida, $\mathrm{C}$. myrica, and $\mathrm{G}$. foliifera AuNPs were shifted to 1643,1643 , and $1637 \mathrm{~cm}^{-1}$ (Fig. 5: a-c). The electronegative combination of AuNPs with the oxygen atom of $\mathrm{C}=\mathrm{O}$ can result in such peak fluctuations. ${ }^{37}$. AuNPs could be stabilized by the aromatics, amines, or alkanes present in the chemical structures of seaweeds. All these changes depict AuNPs association with U. rigida, C. myrica, and $G$. foliifera. Similar results have been reported by González-ballesteros et al. ${ }^{38}$ using Cystoseira, Rajeshkumar et al. using Turbinaria ornata, ${ }^{37}$ Krishnamoorthy et al. using Sargassum muticum, ${ }^{18}$ and Isaac and Renitta using Padina pavonica. ${ }^{16}$

Antimicrobial Activity of Biosynthesized AuNPs

Antimicrobial activities of the eco-friendly and stable gold nanoparticles, biosynthesized using $U$. rigida, C. myrica, and G. foliifera extracts, were evaluated by agar well diffusion and the minimal inhibition methods against different human pathogens. The biosynthesized AuNPs exhibited a varying degree of antimicrobial activities against tested pathogenic microorganisms. The results in Table (1) revealed that $U$. rigida AuNPs were the most effective against tested microorganisms, followed by AuNPs of $C$. myrica and $G$. foliifera, respectively. AuNPs of $U$. rigida extracts exhibited the highest antimicrobial activity against Trichosporon cataneum $(30 \mathrm{~mm})$ followed by Trichophyton mantigrophytes $(25 \mathrm{~mm})$, and $E$. coli $(17 \mathrm{~mm})$ with minimal lethal concentration ranged of 64 to $128 \mu \mathrm{g} / \mathrm{ml}$, while the lowest sensitivity was recorded against $C$. neoformans $(15 \mathrm{~mm})$, C. albicans $(13 \mathrm{~mm})$, and S. aureus $(11 \mathrm{~mm})$, respectively.

Data presented in the current study revealed that these gold nanoparticles exhibited significant antimicrobial activity against dermatophytic fungi and exerted mild effects against Gram-positive and Gram-negative pathogenic bacteria. In contrast,,$^{39}$ found that the antibacterial activity of brown seaweed mediated Ag-NPs and Au-NPs was better than antifungal activity when applied against Pseudomonas aeruginosa, E. coli, Salmonella typhi, and S. aureus, and pathogenic fungi such as Penicillium italicum, Candida albicans, Fusarium equiseti, and Alternaria alternata. The current study shows that the AuNPs capped by U. rigida, C. myrica, and G. foliifera were almost spherical having a size of about 9,11 , and $13 \mathrm{~nm}$ respectively, and exhibited

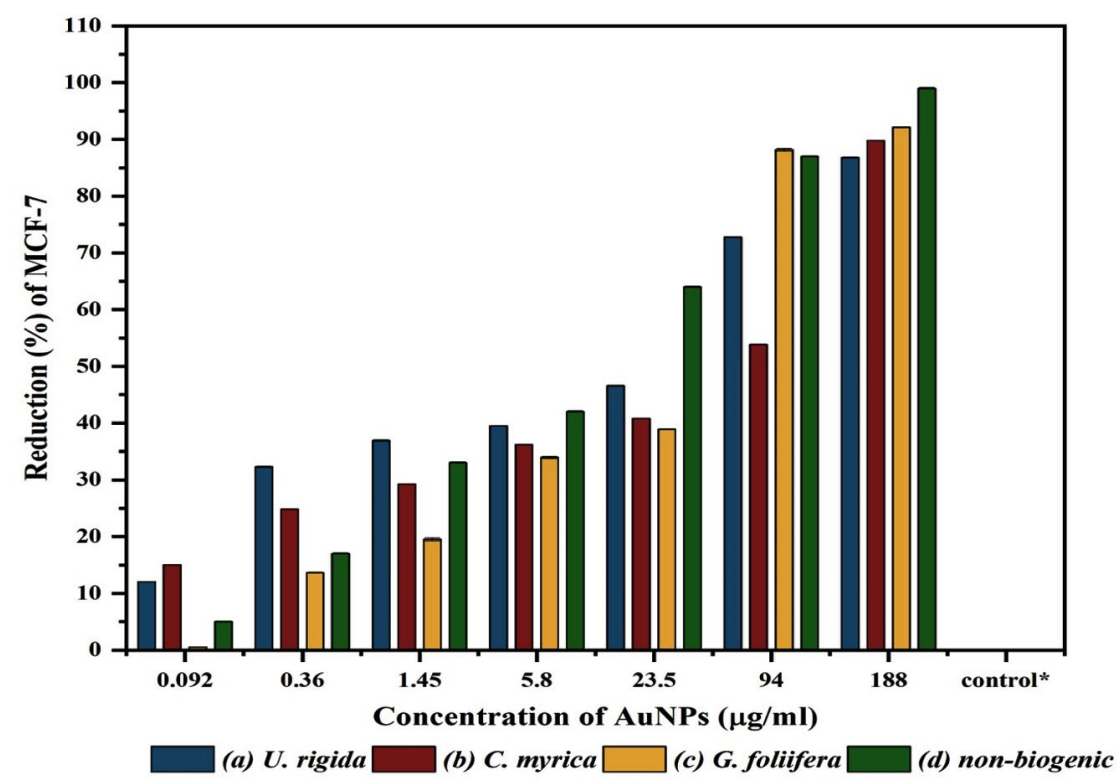

Fig. 9. The reduction (\%) and anticancer activity of different concentrations $(\mu \mathrm{g} / \mathrm{ml})$ of biosynthesized AuNPs capped by different marine algal extracts: (a) U. rigida, (b) C. myrica, (c) G. foliifera, and (d) nonbiogenic AuNPs against Human Brest cancer cell lines (MCF-7) after 24 hours. Each value represents the mean of three samples \pm SD $(n=3)$. 
average antimicrobial activity $(11-30 \mathrm{~mm})$ against tested pathogens. Trichosporon cataneum and Trichophyton mantigrophytes were found to be the most sensitive to all AuNPs algal extracts. However, these AuNPs could not affect Bacillus cereus and Candida albicans. In this context, ${ }^{40}$ has reported that the antifungal activity depends on the nano size of AuNPs. They found that AuNPs having a size of $9 \mathrm{~nm}$ exhibited excellent antifungal activity against Candida species as compared to the gold nanoparticles of $13 \mathrm{~nm}$. It suggests that AuNPs of $9 \mathrm{~nm}$ size better restricted the trans-membrane $\mathrm{H}+$ efflux in Candida species in comparison to gold nanoparticles of $13 \mathrm{~nm}$ size. The minimal lethal values of AuNPs synthesized by the three different algae species ranged from $64-128 \mathrm{ll} / \mathrm{ml}$ (Table 1 ), whereas lethal effects were not detected in Aufree algal extracts at the same concentrations. Furthermore, antimicrobial activity was not observed in the control solution devoid of gold nanoparticles, thus confirming the antimicrobial potential of AuNPs. Rajathi et al ${ }^{41}$ have reported the effectiveness of brown alga (Stoechospermum marginatum) mediated AuNPs against bacterial pathogens and stated that the hydroxyl groups of brown algae diterpenoids are responsible for the formation of the nanoparticles. ${ }^{41}$ Cui et al. ${ }^{42}$ have elaborated the mechanism of biosynthesized AuNPs and found that they follow two pathways to express the antimicrobial activity 1 ) by altering membrane potential and inhibiting ATP synthase activity to reduce ATP level that indicates decreased metabolism 2) by preventing the ribosomal subunit from RNA binding to stop the biological process. AuNPs also enhance chemotaxis during the early-phase reaction. Au-NPs can attack multiple targets to effectively counter the bacteria, which are resistant to a variety of drugs. The bactericidal Au-NPs do not induce any process related to ROS (reactive oxygen species), which causes cellular death against other antibacterial nanomaterials and antibiotics. However, some studies have reported that gold ions react with $\mathrm{SH}$ groups of proteins to inactivate the bacteria. ${ }^{43}$ The gold ions have also been reported to affect oxidative phosphorylation to release respiratory electron transport, thus altering the membrane permeability to phosphate and proton and inhibit respiratory chain enzymes. ${ }^{44}$ The presence of sulfur and gold NPs in the electron-dense granules of bacterial cell cytoplasm after gold NP treatment reveals the interaction between nucleic acids and

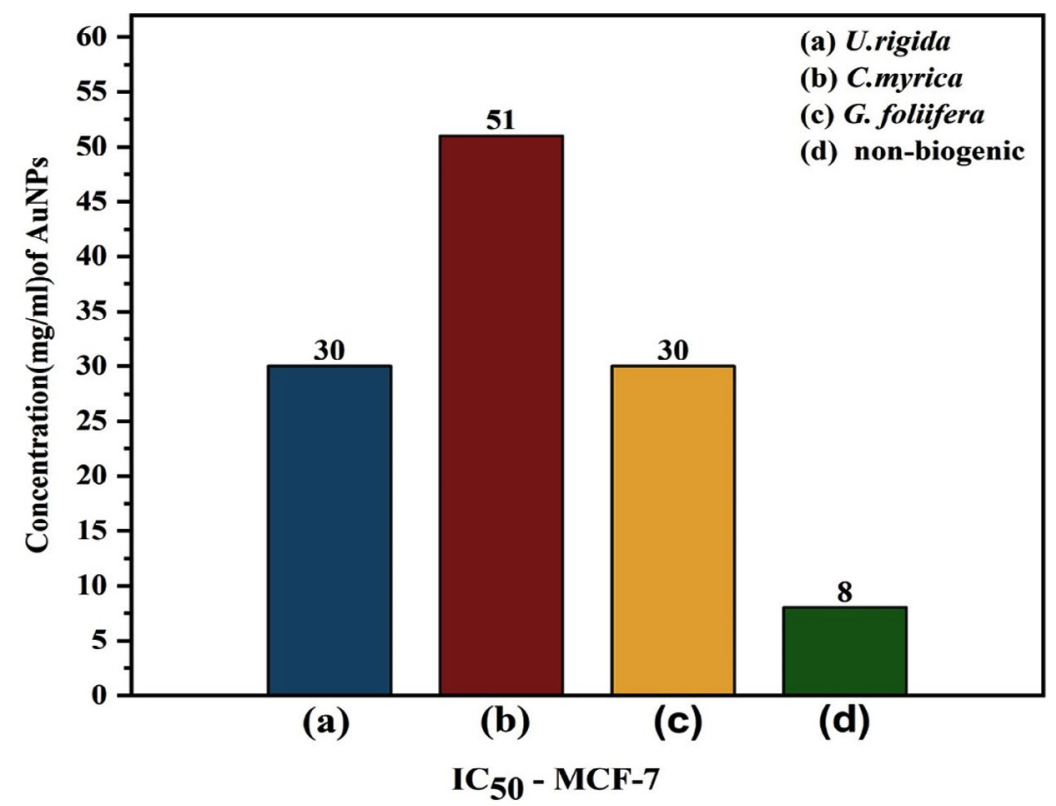

Fig. 10. $I C_{50}$ values of different concentrations $(\mu \mathrm{g} / \mathrm{ml})$ of biosynthesized AuNPs capped by different marine algal extracts: (a) U. rigida, (b) C. myrica, (c) G. foliifera, and non-biogenic AuNPs against Human Breast cancer cell line (MCF-7) after 24 hours. Each value represents the mean of three samples \pm SD $(n=3)$. 
AuNPs that disturbs DNA replication. Therefore, the application of biosynthesized gold NPs for the disease management could be inferred. A proteomic analysis has recently demonstrated that $E$. coli cells exposure to nanogold even for a short period could alter the expression of heat sock protein and a panel of envelope, ${ }^{45}$ which depicts the disruption of bacterial membranes by these particles. Nanogolds are known to significantly decrease intracellular potassium and reduce ATP levels. Nanogold could possibly target the respiratory enzymes (Protein thiol groups) at molecular level. Nanogold could also possibly target the phospholipids present in the bacterial membrane. The results of this study concluded that the gold nanoparticles exhibited significant antimicrobial activity against dermatophytic fungi and mild effects against Gram-positive and Gram-negative foodborne pathogenic bacteria. Thus, the AuNPs synthesized by algal extracts during this study might be a good alternative to develop antimicrobial agents against the multidrug-resistant bacterial and fungi strains. The applications of AuNPs capped by marine
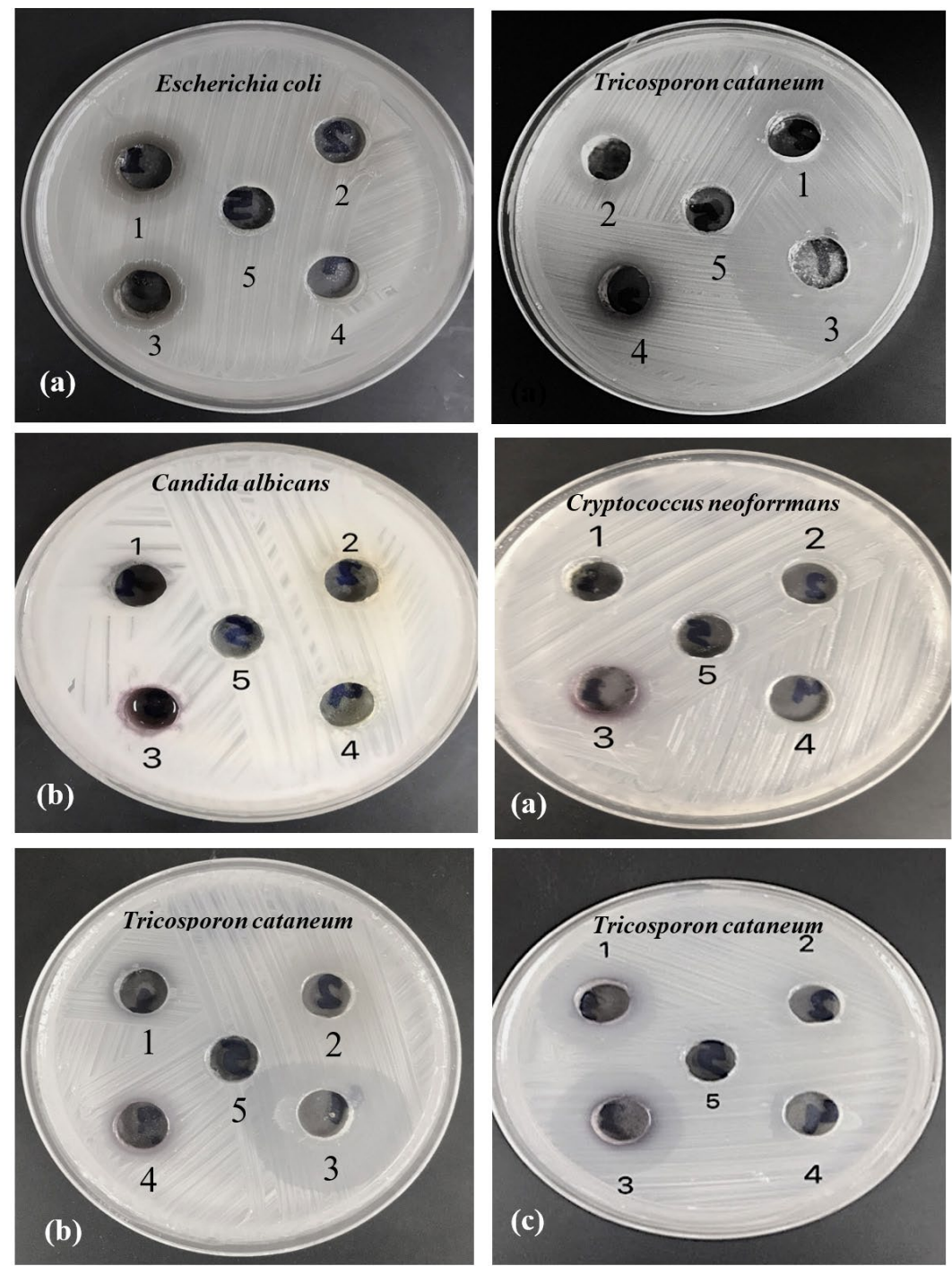

Fig. 11. Antimicrobial activity of biosynthesized AuNPs capped by (a) U. rigida, (b) C. myrica, and (c) G. foliifera against tested pathogenic microorganisms as indicated by clear zone diameter (CZD, mm). (1) AuNPs Aqueous, (2) Aqueous extract, (3) AuNPs Ethanol extract, (4) Ethanol extract, and (5) Control. 
algal extracts may lead to valuable findings of antimicrobial and anticancer properties. ${ }^{19,41,46}$

Cytotoxicity and Anticancer Activity of Biosynthesized AuNPs

Cytotoxicity of the biosynthesized AuNPs was assessed using Artemia salina nauplii, regular skin cell lines, and breast cancer cell lines. Firstly, cytotoxicity of the AuNPs capped by different algal biomolecules was evaluated against Artemia nauplii as illustrated in Fig. $6 . \mathrm{LC}_{50}$ values of AuNPs synthesized by U. rigida, C. myrica, and G. foliifera extracts against Artemia salina were noted as 5 , 10 , and $5 \mu \mathrm{g} / \mathrm{ml}$ after 16,14 , and $24 \mathrm{~h}$, respectively. Secondly, cytotoxicity of the biosynthesized AuNPs was also evaluated against Human skin cell line (HFb-4). Data in Fig. (7) reveals that the cytotoxicity of AuNPs to HFb-4 was concentration-dependent as the cell viability gradually decreased with the rising concentrations. The concentrationdependent viability of the normal skin cell line was observed against AuNPs biosynthesized by different algal extracts and non-biogenic AuNPs. The viability values at the lower concentrations $(0.092 \mu \mathrm{g} / \mathrm{ml})$ of U. rigida, G. foliifera, and C. myrica AuNPs were calculated as 96.08, 91.77, and $88.24 \%$ whereas $58 \%$ cell viability was noted against non-biogenic AuNPs. The survivability of normal skin cell line ( $\mathrm{Hfb}-4)$ significantly decreased at a higher concentration of $188 \mu \mathrm{g} / \mathrm{ml}$ to 19.07 , 13.3 , and $10.1 \%$ against $C$. myrica, $G$. foliifera, and $U$. rigida AuNPs, respectively. Contrarily, agonizing cell mortality was recorded against non-biogenic AuNPs $(0.1 \%)$ at the same concentration. The highest cytotoxicity levels $\left(\mathrm{IC}_{50}\right)$ were recorded against $C$. myrica $(102 \mu \mathrm{g} / \mathrm{ml}), G$. foliifera $(64 \mu \mathrm{g} /$ $\mathrm{ml}$ ) followed by $U$. rigida $(32 \mu \mathrm{g} / \mathrm{ml})$, and nonbiogenic AuNPs (0.15 $\mu \mathrm{g} / \mathrm{ml}$ ) Fig. (8).

Thirdly, Sulforhodamine B (SRB) method was followed to assess the anticancer potential of biosynthesized AuNPs against the MCF-7 cell line. Serial fold concentrations of biosynthesized AuNPs were prepared up to $188 \mu \mathrm{g} / \mathrm{ml}$ and their anticancer activity was estimated in comparison to non-biogenic AuNPs. The data presented in Fig 9 show an increasing trend in the reduction values of MCF-7 cells against increasing AuNPs concentrations. G. foliifera AuNPs presented the highest anticancer value (92.13\%) against MCF-7 cells at a concentration of $188 \mu \mathrm{g} / \mathrm{ml}$ followed by C. myrica $(89.82 \%)$, and U. rigida $(86.83 \%)$, respectively. Compared to the biosynthesized AuNPs, the non-biogenic AuNPs exhibited the highest anticancer values (99\%) but simultaneously the highest toxicity was also noticed. $\mathrm{IC}_{50}$ values of biosynthesized C. myrica, U. rigida, and $G$. foliifera AuNPs were noted as 51, 30, $30(\mu \mathrm{g} / \mathrm{ml})$, respectively whereas the $\mathrm{IC}_{50}$ of non-biogenic AuNPs remained as $8 \mu \mathrm{g} / \mathrm{ml}$ (Fig. 10).

Cancer is a serious global issue and the development of effective anticancer drugs is quite challenging. Breast cancer is the most common type all over the world. The incidence rate of breast cancer has reached up to $30 \%$ in the new female cancers. ${ }^{47,48}$ Biosynthesized nanoparticles (NPs) have emerged as promising novel therapeutic agents. These nanoparticles can facilitate to counter cancer and infectious diseases, and pathogenic drug resistance. Therefore, the search for new antimicrobials and anticancer agents is inevitable. ${ }^{49,50}$ The marine algae phytochemicals including amino functional groups, carboxyl, and hydroxyl can effectively act as capping and metalreducing agents during coating on the metal NPs. Au-NPs green biosynthesis is a pollutantfree, simple, low-cost, and environment-friendly approach. Algae-mediated NPs could exert excellent cytotoxic and antimicrobial effects. In the current study, cytotoxicity and anticancer activities of the AuNPs, synthesized by different algal species, were assessed against $\mathrm{Hfb}-4$ and MCF-7 cell lines in comparison to non-biogenic ascorbic acid. Interestingly, these biosynthesized AuNPs exhibited less toxicity to skin cell lines $(\mathrm{Hfb}-4)$ than non-biogenic AuNPs and produced significant anticancer activity against MCF-7 cell line even at a very low AuNPs concentration. Furthermore, anticancer activity of different algal extracts based AuNPs against MCF-7 cell lines was found to be dose-dependent. Strong anti-cancerous activities of algae-based AuNPs against different cell lines have been reported. In a similar study, Singh et al. ${ }^{48}$ found that the cytotoxicity effects of algae-based AuNPs against normal MCF-10A breast cells and cancerous MCF-7 cells presented a precise time- and dosedependent trend and observed approximately $35 \%$ cell mortality at $200 \mu \mathrm{g} / \mathrm{ml}$ concentration after $24 \mathrm{~h}$. The cytotoxicity resulted in cell shrinkage, distorted morphological structure, and apoptosis in cancer cells. Dose-dependent anticancer 
potential of Chaetomorpha linum-mediated AuNPs against HCT-116 colon cancer cell line has also been reported in another study. ${ }^{51}$ Several studies have reported the anticancer mechanism of AuNPs in vivo and in vitro. ${ }^{48,51-55}$ The mechanisms behind the anticancer activity of biogenic AuNPs might include ROS overproduction and caspase cascades activation to induce cell apoptosis. ${ }^{54,55}$ FTIR and UV-Visible Spectroscopy analysis data of this study indicated that the biomolecules such as terpenoids, polyphenols, carotenoids, sulfonates polysaccharides (fucoidans), carbohydrates, lipids, sterols, and agar possibly participated in the AuNPs reduction and served as stabilizing, capping, antimicrobial and anticancer agents. Similar studies have reported the detection of biomolecules such as polyphenols, polysaccharides, fatty acids, ionic trace minerals, vitamins, enzymes, flavonoids, amino acids, fucoidans, lipids, terpenoids, chlorophylls, carbohydrates, alkaloids, pyruvic acid, and aliphatic fluoro compounds in Ulva rigida, Cystoseira myrica, and Gracilaria foliifera aqueous extracts that might be involved in anticancer and antimicrobial activities. ${ }^{53,56}$ The preliminary results of this study revealed a significant anticancer efficacy of biosynthesized AuNPs against cancerous MCF-7 cell lines, however, further in vivo studies on animal models are required to elaborate exact potential. The vagueness and challenges related to biogenic AuNPs such as pharmacokinetics, genotoxicity, therapeutic window, pharmacodynamics, and safety profile should also be addressed in future studies.

\section{CONCLUSION}

From these results, it could be concluded that algal-mediated AuNPs are mostly possessed spherically shaped NPs with sizes ranging from 9 to $13 \mathrm{~nm}$. The AuNPs synthesized by different algal extracts showed significant antifungal activity against dermatophytic fungi and exerted mild effects against the foodborne bacterial pathogens. Furthermore, the biosynthesized AgNPs particularly the $U$. rigida AgNPs exhibited significant anticancer activity against MCF-7 cell lines and have no toxicity against both Artemia salina nauplii and skin cell lines. So, the $U$. rigida AgNPs could potentially serve as efficient alternative anticancer agents against human breast adenocarcinoma and anti-dermatophytes associated with skin infections.

\section{ACKNOWLEDGMENTS}

None.

\section{CONFLICT OF INTEREST}

The authors declare that there is no conflict of interest.

\section{AUTHORS' CONTRIBUTION}

All authors listed have made a substantial, direct and intellectual contribution to the work, and approved it for publication.

\section{FUNDING}

None.

\section{DATA AVAILABILITY}

All datasets generated or analyzed during this study are included in the manuscript.

\section{ETHICS STATEMENT}

This article does not contain any studies with human participants or animals performed by any of the authors.

\section{REFERENCES}

1. Vijayan SR, Santhiyagu P, Ramasamy R, et al. Seaweeds: A resource for marine bionanotechnology. Enzyme Microb Technol. 2016;95:45-57. doi: 10.1016/j. enzmictec.2016.06.009

2. El-sheekh MM, El-kassas HY. Algal production of nano-silver and gold: Their antimicrobial and cytotoxic activities: A review. J Genet Eng Biotechnol.2016;14(2):299-310. doi: 10.1016/j. jgeb.2016.09.008

3. Ponnuchamy K, Jacob JA. Metal nanoparticles from marine seaweeds - A review. Nanotechnol. Rev. 2016;5(6):589-600. doi: 10.1515/ntrev-2016-0010

4. Fawcett D, Verduin JJ, Shah M, Sharma SB, Poinern GEJ. A Review of Current Research into the Biogenic Synthesis of Metal and Metal Oxide Nanoparticles via Marine Algae and Seagrasses. J Nanosci. 2017;2017:8013850. doi: 10.1155/2017/8013850

5. Roy S. A Review: Green Synthesis of Nanoparticles from Seaweeds and Its some Applications. Austin J Nanomed Nanotechnol. 2019;7(1):1054.

6. Arya A, Chundawat TS. Metal Nanoparticles from Algae: A Green Approach for the Synthesis, Characterization and their Biological Activity. Nanosci NanotechnologyAsia 2020;10(3):185-202. doi: 10.2174/22106812096 66181212153701

7. Davis TA, Volesky B, Mucci A. A review of the biochemistry of heavy metal biosorption by brown 
algae. Water Res. 2003;37(18):4311-4330. doi: 10.1016/S0043-1354(03)00293-8

8. El Zokm GM, Ismail MM, El-Said GF. Halogen content relative to the chemical and biochemical composition of fifteen marine macro and micro algae: nutritional value, energy supply, antioxidant potency, and health risk assessment. Environ Sci Pollut Res. 2021;28(12):14893-14908. doi: 10.1007/s11356-02011596-0

9. Ramkumar VS, Pugazhendhi A, Gopalakrishnan K, et al. Biofabrication and characterization of silver nanoparticles using aqueous extract of seaweed Enteromorpha compressa and its biomedical properties. Biotechnol Reports. 2017;14:1-7. doi: 10.1016/j.btre.2017.02.001

10. Dreaden EC, Alkilany AM, Huang X, Murphy CJ, ElSayed MA. The golden age: Gold nanoparticles for biomedicine. Chem Soc Rev. 2012; 41(7):2740-2779. doi: 10.1039/C1CS15237H

11. Singaravelu G, Arockiamary JS, Kumar VG, Govindaraju K. A novel extracellular synthesis of monodisperse gold nanoparticles using marine alga, Sargassum wightii Greville. Colloids Surfaces B Biointerfaces. 2007;57(1):97-101. doi: 10.1016/j. colsurfb.2007.01.010

12. Vijayaraghavan K, Mahadevan A, Sathishkumar M, Pavagadhi S, Balasubramanian R. Biosynthesis of $\mathrm{Au}(0)$ from $\mathrm{Au}$ (III) via biosorption and bioreduction using brown marine alga Turbinaria conoides. Chem Eng J. 2011;167(1):223-227. doi: 10.1016/j.cej.2010.12.027

13. Govindaraju K, Kiruthiga V, Kumar VG, Singaravelu G. Extracellular synthesis of silver nanoparticles by a marine alga, Sargassum wightii grevilli and their Antibacterial effects. J Nanosci Nanotechnol. 2009;9(9):5497-5501. doi: 10.1166/jnn.2009.1199

14. Ananthi S, Raghavendran HRB, Sunil AG, Gayathri V, Ramakrishnan G, Vasanthi HR. In vitro antioxidant and in vivo anti-inflammatory potential of crude polysaccharide from Turbinaria ornata (Marine Brown Alga). Food Chem Toxicol. 2010;48(1):187-192. doi: 10.1016/j.fct.2009.09.036

15. Rajabi S, Ramazani A, Hamidi M, Naji T. Artemia salina as a model organism in toxicity assessment of nanoparticles. DARU J Pharm Sci. 2015;23(1):20. doi: 10.1186/s40199-015-0105-x

16. Isaac G, Renitta RE. Brown Algae mediated synthesis, characterization of gold nano particles using Padina pavonica and their antibacterial activity against human pathogens. International Journal of PharmTech Research. 2015;8(9)31-40.

17. Leonel P, Neto MJ. Marine algae: biodiversity, taxonomy, environmental assessment, and biotechnology. CRC Press. 2014:398.

18. Krishnamoorthy K, Alsagaby SA, Singaravelu G, Govindaraju K, Premanathan M. Green synthesis of silver nanoparticles for selective toxicity towards cancer cells. IET Nanobiotechnol. 2015;9(6):325-330. doi: 10.1049/iet-nbt.2015.0001

19. Abdel-Raouf N, Al-Enazi N, Ibraheem I. Green biosynthesis of gold nanoparticles using Galaxaura elongata and characterization of their antibacterial activity. Arab J Chem. 2017;10(Supp 2):S3029-S3039. doi: 10.1016/j.arabjc.2013.11.044

20. Dhas TS, Kumar VG, Karthick V, Govindaraju K, Narayana TS. Spectrochimica Acta Part A : Molecular and Biomolecular Spectroscopy Biosynthesis of gold nanoparticles using Sargassum swartzii and its cytotoxicity effect on HeLa cells. Spectrochim Acta Part A: Mol Biomol Spectrosc. 2014;133:102-106. doi: 10.1016/j.saa.2014.05.042

21. Woehrle GH, Hutchison JE, Ozkar S, Finke R. Analysis of nanoparticle transmission electron microscopy data using a public-domain image-processing program, Image. Turk. J. Chem. 2006: 30: 1-13.

22. El-Kassas HY, El-Sheekh MM. Cytotoxic activity of biosynthesized gold nanoparticles with an extract of the red seaweed Corallina officinalis on the MCF-7 human breast cancer cell line. Asian Pacific J Cancer Prev. 2014;15(10):4311-4317. doi: 10.7314/ APJCP.2014.15.10.4311

23. Singh M, Kalaivani R, Manikandan S, Sangeetha N, Kumaraguru AK. Facile green synthesis of variable metallic gold nanoparticle using Padina gymnospora, a brown marine macroalga. App/ Nanosci. 2013;3(2):145151. doi: 10.1007/s13204-012-0115-7

24. Azizi S, Ahmad MB, Namvar F, Mohamad R. Green biosynthesis and characterization of zinc oxide nanoparticles using brown marine macroalga Sargassum muticum aqueous extract. Mater Lett. 2014;116:275-277. doi: 10.1016/j.matlet.2013.11.038

25. Galandakova A, Frankova J, Ambrozova N, et al. Effects of silver nanoparticles on human dermal fibroblasts and epidermal keratinocytes. Hum Exp Toxicol. 2016;35(9):946-957. doi: 10.1177/0960327115611969 26. Bhimba BV, Devi JS, Nandhini SU. Green synthesis and cytotoxicity of silver nanoparticles from extracts of the marine macroalgae Gracilaria corticata. Indian J Biotechnol. 2015;14(1):276-281.

27. Mofeed J, Deyab MA, El-halim EHA. Anticancer Activity of Some Filamentous Cyanobacterial Isolates against Hep-G2 and MCF-7 Cancer Cell lines. Int J Life Sci. 2018;8(1):10-17.

28. Torres A, Garedew A, Schmolz E, Lamprecht I. Calorimetric investigation of the antimicrobial action and insight into the chemical properties of 'angelita' honey - A product of the stingless bee Tetragonisca angustula from Colombia. Thermochim Acta. 2004;415(1-2):107-113. doi: 10.1016/j. tca.2003.06.005

29. Elbanna K, Assiri AMA, Tadros M, et al. Rosemary (Rosmarinus officinalis) oil: composition and functionality of the cold-pressed extract. J Food Meas Charact. 2018;12(3):1601-1609. doi: 10.1007/ s11694-018-9775-7

30. Bauer AW, Kirby WMM, Sherris JC, Turck M. Antibiotic susceptibility testing a standardized single disk method. Am J Clin Pathol. 1966;45(4):493-496. doi: 10.1093/ajcp/45.4_ts.493

31. Murugesan S, Bhuvaneswari S, Shanthi N, Murugakoothan P, Sivamurugan V. Red alga Hypnea musciformis (Wulf) Lamour mediated environmentally benign synthesis and antifungal activity of gold nano particles. Int J Nanosci Nanotechnol. 2015;6(1):71-83. 32. Al-Rubaye HI, Al-Rubaye BK, Al-Abodi EE, Yousif 
El. Green Chemistry Synthesis of Modified Silver Nanoparticles. J Phys Conf Ser. 2020;1664(1):1-26. doi: 10.1088/1742-6596/1664/1/012080

33. Lee SM, Song KC, Lee BS. Antibacterial activity of silver nanoparticles prepared by a chemical reduction method. Korean J Chem Eng. 2010;27(2):688-692. doi: 10.1007/s11814-010-0067-0

34. Song JY, Kim BS. Rapid biological synthesis of silver nanoparticles using plant leaf extracts. Bioprocess Biosyst Eng. 2009;32(1):79-84. doi: 10.1007/s00449008-0224-6

35. Roy N, Mondal S, Laskar RA, Basu S, Mandal D, Begum NA. Biogenic synthesis of Au and Ag nanoparticles by Indian propolis and its constituents. Colloids Surfaces B Biointerfaces. 2010;76(1):317-325. doi: 10.1016/j. colsurfb.2009.11.011

36. Kajani AA, Bordbar AK, Esfahani SHZ, Khosropour $A R$, Razmjou A. Green synthesis of anisotropic silver nanoparticles with potent anticancer activity using Taxus baccata extract. RSC Adv. 2014;4(106):6139461403. doi: $10.1039 / C 4 R A 08758 E$

37. Rajeshkumar S, Malarkodi C, Gnanajobitha G, et al. Seaweed-mediated synthesis of gold nanoparticles using Turbinaria conoides and its characterization. Journal of Nanostructure in chemistry. 2014;3:44. doi: 10.1186/2193-8865-3-44

38. Gonzalez-ballesteros N, Prado-lopez S, Rodriguezgonzalez JB, Lastra M. Green synthesis of gold nanoparticles using brown algae Cystoseira baccata: Its activity in colon cancer cells. Colloids and Surfaces B : Biointerfaces. 2017;153:190-198. doi: 10.1016/j. colsurfb.2017.02.020

39. Kayalvizhi K, Subramanian V, Boopathy NS, Kathiresan K. Antioxidant properties of brown seaweeds Turbinaria ornata (Turner) J. Agardh, 1848 and Padina tetrastromatica (Hauck). Biotechnol. 2014;(6):29-37.

40. Ahmad T, Wani IA, Lone IH, et al. Antifungal activity of gold nanoparticles prepared by solvothermal method. Mater Res Bull. 2013;48(1):12-20. doi: 10.1016/j. materresbull.2012.09.069

41. Rajathi FAA, Parthiban C, Kumar VG, Anantharaman P. Biosynthesis of antibacterial gold nanoparticles using brown alga, Stoechospermum marginatum (kutzing). Spectrochim Acta - Part A Mol Biomol Spectrosc. 2012;99:166-173. doi: 10.1016/j.saa.2012.08.081

42. Cui Y, Zhao Y, Tian Y, Zhang W, LuX, Jiang X. The molecular mechanism of action of bactericidal gold nanoparticles on Escherichia coli. Biomaterials. 2012;33(7):23272333. doi: 10.1016/j.biomaterials.2011.11.057

43. Guzman MG, Dille J, Godet S. Synthesis of silver nanoparticles by chemical reduction method and their antibacterial activity. World Academy of Science, Engineering and Technology. 2008;19:357-364.

44. Feng J, Shi J, Sirimanne SR, Mounier-Lee CE, May SW. Kinetic and stereochemical studies on novel inactivators of C-terminal amidation. Biochem J. 2000;350(2):521-530. doi: 10.1042/bj3500521

45. Eom SH, Kim YM, Kim SK. Antimicrobial effect of phlorotannins from marine brown algae. Food Chem Toxicol. 2012;50(9):3251-3255. doi: 10.1016/j. fct.2012.06.028

46. Babu B, Palanisamy S, Vinosha M, et al. Bioengineered gold nanoparticles from marine seaweed Acanthophora spicifera for pharmaceutical uses: antioxidant, antibacterial, and anticancer activities. Bioprocess Biosyst Eng. 2020;43(12):2231-2242. doi: 10.1007/ s00449-020-02408-3

47. Siegel RL, Miller KD, Jemal A. Cancer statistics, 2019. CA Cancer J Clin. 2019;69(1)7-34. doi: 10.3322/caac.21551

48. Singh AK, Tiwari R, Singh VK, et al. Green synthesis of gold nanoparticles from Dunaliella salina, its characterization and in vitro anticancer activity on breast cancer cell line. J Drug Deliv Sci Technol. 2019;51:164-176. doi: 10.1016/j.jddst.2019.02.023

49. Yoon HS, Muller KM, Sheath RG, Ott FD, Bhattacharya D. Defining the major lineages of red algae (Rhodophyta). J Phycol. 2006;42(2):482-492. doi: 10.1111/j.15298817.2006.00210.x

50. Jeyarani S, Vinita NM, Puja P, et al. Biomimetic gold nanoparticles for its cytotoxicity and biocompatibility evidenced by fluorescence-based assays in cancer (MDA-MB-231) and non-cancerous (HEK-293) cells. J Photochem Photobiol B Biol. 2020;202:111715. doi: 10.1016/j.jphotobiol.2019.111715

51. El-Sheekh MM, El-Kassas HY. Algal production of nano-silver and gold: Their antimicrobial and cytotoxic activities: A review. J Genet Eng Biotechnol. 2016;14(2):299-310. doi: 10.1016/j.jgeb.2016.09.008

52. Boopathy NS, Kathiresan K. Anticancer drugs from marine flora: An overview. J Oncol. 2010;2010:214186. doi: 10.1155/2010/214186

53. Mashoor S, Yousefzadi MY, Esmaeili MA, Rafiee R. Cytotoxicity and antimicrobial activity of marine macro algae (Dictyotaceae and Ulvaceae) from the Persian Gulf. Cytotechnology. 2016;68(5):1717-1726. doi: 10.1007/s10616-015-9921-6

54. Namvar F, Rahman HS, Mohamad R, et al. Cytotoxic Effects of Biosynthesized Zinc Oxide Nanoparticles on Murine Cell Lines. Evidence-Based Complementary and Alternative Medicine. 2015;2015:593014. doi: 10.1155/2015/593014

55. Namvar F, Rahman H, Mohamad R, et al. Cytotoxic effect of magnetic iron oxide nanoparticles synthesized via seaweed aqueous extract. Int I Nanomedicine. 2014;9(1):2479-2488. doi: 10.2147/IJN.S59661

56. Pacheco BS, dos Santos MAZ, Schultze E, et al. Cytotoxic activity of fatty acids from Antarctic macroalgae on the growth of human breast cancer cells. Front Bioeng Biotechnol. 2018;6:185. doi: 10.3389/ fbioe.2018.00185 